MaPan : Jurnal Matematika dan Pembelajaran

p-ISSN: 2354-6883 ; e-ISSN: 2581-172X

Volume 6, No 1, June 2018 (70-81)

DOI: https://doi.org/10.24252/mapan.2018v6n1a7

\title{
PENINGKATAN INTELEGENSI DAN HASIL BELAJAR SISWA MELALUI PEMBELAJARAN FUNGSI LOGARITMA MENGGUNAKAN MODEL QUANTUM LEARNING
}

\author{
Siti Masliani \\ Madrasah Aliyah Negeri 1 Banjarmasin \\ Jl. Kampung Melayu Darat Rt. 11 No. 31 Banjarmasin 70123 \\ E-mail: s.m4sliani@gmail.com
}

Submitted: 24-02-2018, Revised: 09-05-2018, Accepted: 09-05-2018

\begin{abstract}
Abstrak:
Tujuan penelitian ini adalah untuk mengetahui peningkatan aktivitas guru, aktivitas siswa, intelegensi siswa, dan hasil belajar siswa terhadap pembelajaran dengan menggunakan model quantum learning. Penelitian ini menggunakan rancangan Penelitian Tindakan Kelas (PTK) dengan 2 siklus. Masing-masing siklus terdiri dari tahap perencanaan, pelaksanaan tindakan, observasi dan evaluasi, serta analisis dan refleksi. Subjek dalam penelitian ini adalah siswa kelas X MIA 1 dengan jumlah siswa sebanyak 34 orang. Data yang dikumpulkan menggunakan teknik observasi dan tes hasil belajar, selanjutnya dianalisis dengan teknik analisis deskriptif kuantitatif dan analisis kualitatif. Hasil penelitian menunjukkan bahwa penggunaan model quantum learning pada materi fungsi logaritma dapat meningkatkan aktivitas guru, aktivitas siswa, intelegensi, dan hasil belajar siswa.
\end{abstract}

Kata Kunci: Model Pembelajaran, Quantum Learning, Hasil Belajar, Fungsi Logaritma

\section{INTELLIGENCE IMPROVEMENT AND STUDENT ACHIEVEMENT THROUGH LOGARITHMATIC FUNCTION LEARNING USING QUANTUM LEARNING MODEL}

\begin{abstract}
:
The purpose of this research is to find out the improvement of teacher activity, student activity, student intelligence, and student learning outcomes to the learning quantum learning model which implemented. The classroom action research design with 2 cycles was used in this study. Each cycle consists of the following stages: planning, implementation of action, observation and evaluation, analysis and reflection. The subjects of this study were 34 students of class X MIA 1. The collected data were conducted using observation technique and the learning result test, and then, they were analyzed by using quantitative descriptive analysis technique and qualitative analysis. The result of this research shows that the quantum learning model can be used to improve teacher activity, student activity, student intelligence, and students' learning outcomes.
\end{abstract}

Keywords: Learning Model, Quantum Learning, Learning Outcomes, Logarithmic Functions 
How to Cite: Masliani, S. (2018). Peningkatan Intelegensi dan Hasil Belajar Siswa melalui Pembelajaran Fungsi Logaritma Menggunakan Model Quantum Learning. MaPan : Jurnal Matematika dan Pembelajaran, 6 (1), 70-81.

$\mathrm{P}$ erkembangan zaman yang semakin modern terutama pada era globalisasi seperti sekarang ini menuntut adanya sumber daya manusia yang berkualitas tinggi. Peningkatan kualitas sumber daya manusia merupakan prasyarat mutlak untuk mencapai tujuan pembangunan. Salah satu wahana untuk meningkatkan kualitas sumber daya manusia tersebut adalah pendidikan. Pendidikan merupakan suatu aspek kehidupan yang sangat mendasar bagi pembangunan bangsa suatu negara. Dalam penyelenggaraan pendidikan di sekolah yang melibatkan guru sebagai pendidik dan siswa sebagai peserta didik, diwujudkan dengan adanya interaksi belajar mengajar atau proses pembelajaran (Iskandar, 2009).

Salah satu usaha yang digunakan untuk mewujudkan tujuan tersebut adalah meningkatkan hasil belajar siswa. Prestasi belajar merupakan tolak ukur yang utama untuk mengetahui keberhasilan belajar. Seseorang yang prestasinya tinggi dapat dikatakan bahwa ia telah berhasil dalam belajar. Pengenalan terhadap faktor-faktor yang mempengaruhi prestasi belajar penting sekali artinya dalam rangka membantu murid dalam mencapai prestasi belajar yang sebaik-baiknya (Ahmadi, 2004).

Gambaran tentang anak yang berintelegensi tinggi adalah gambaran mengenai siswa yang pintar dimana siswa tersebut memiliki kemampuan untuk memahami dan menyelesaikan masalah dengan cepat, kemampuan mengingat, kreativitas yang tinggi, dan imajinasi yang berkembang.

Dalam bidang akademis, tingkat kecerdasan atau intelegensi (IQ) seorang individu tidak dapat diragukan lagi sangat menentukan tingkat keberhasilan belajar individu tersebut. Semakin tinggi kemampuan intelegensi individu tersebut tersebut maka semakin besar peluangnya untuk meraih sukses dibidang akademis. Sebaliknya, semakin rendah kemampuan intelegensi seorang individu maka semakin kecil peluang untuk meraih sukses di bidang akademis. Secara umum dipahami bahwa seseorang yang mempunyai tingkat intelegensi yang lebih tinggi memiliki potensi besar untuk berprestasi secara akademik, lebih mampu mengikuti materi yang diajarkan dan berpeluang besar untuk meraih keberhasilan kerja. Meski demikian, dalam penelitian yang dilakukan oleh (Maslihah, 2011) menyimpulkan bahwa prestasi akademik siswa juga dapat dipengaruhi oleh dukungan sosial. 
Intelegensi merupakan salah satu faktor internal yang mempengaruhi prestasi akademik seseorang. Intelegensi sendiri dalam perspektif psikologi memiliki arti yang beraneka ragam. Begitu banyak definisi tentang intelegensi yang dikemukakan oleh para ahli. Definisi intelegensi itu mengalami berbagai perubahan dari waktu ke waktu, tetapi sejak dahulu tidak pernah mengurangi penekanan pada aspek kognitifnya. Salah satu cara yang sering digunakan untuk menyatakan tinggi rendahnya tingkat intelegensi adalah menerjemahkan hasil tes intelegensi ke dalam angka yang dapat menjadi petunjuk mengenai kedudukan tingkat kecerdasan seseorang bila dibandingkan secara relatif terhadap suatu norma. Secara tradisional, angka normatif dari hasil tes intelegensi dinyatakan dalam bentuk rasio (quotient) dan dinamai IQ (intelligence quotient) (Budiman, 2009).

Hasil yang serupa dijumpai dalam penelitian yang dilakukan (Sukiarti, 2009) pada sampel penelitian sebanyak 180 siswa. Pada penelitiannya menunjukkan bahwa terdapat hubungan positif yang signifikan antara intelegensi dengan prestasi akademik. Diperoleh bahwa secara parsial intelegensi dan motivasi belajar berpengaruh sangat nyata terhadap prestasi akademik dan konstribusi (sumbangan) dari variabel intelegensi yang cukup besar. Hal ini terjadi karena seseorang yang memiliki intelegensi baik (dengan IQ tinggi) umumnya mudah belajar dan hasilnya pun cenderung baik. Sebaliknya orang yang intelegensinya rendah cenderung mengalami kesukaran dalam belajar, lambat berpikir, sehingga prestasi akademiknya pun rendah.

Berdasarkan hasil prapenelitian yang telah dilakukan pada siswa Madrasah Aliyah Negeri 1 Banjarmasin kelas X MIA 1, dapat diketahui bahwa hasil belajar dan tingkat intelegensinya rendah. Ini dapat dibuktikan dengan adanya hasil pretest terhadap hasil belajar dan intelegensi yang telah dilakukan dimana dari 34 siswa terdapat 16 siswa atau 47,05\% yang mendapatkan nilai di bawah kriteria belajar minimal (KBM) dan 20 dari 34 siswa atau 58,82\% memiliki tingkat intelegensi yang rendah. Melihat permasalahan tersebut, diperlukan tindakan yang nyata dari guru untuk meningkatkan intelegensi dan hasil belajar siswa, maka perlu adanya perubahan model dalam melaksanakan proses pembelajaran. Salah satu model yang dapat digunakan ialah model pembelajaran quantum learning (DePorter \& Hernacki, 1992). Melalui quantum learning, siswa akan diajak belajar dalam suasana yang lebih nyaman dan menyenangkan sehingga siswa akan lebih bebas dalam menemukan berbagai pengalaman baru dalam belajarnya (Adi, 
Dafik, Hobri, \& Sugeng, 2013). Pendekatan quantum learning ini juga telah diterapkan oleh (Adityarini, Waluyo, \& Aprilya, 2013) untuk meningkatkan motivasi dan hasil belajar siswa.

Model quantum learning ini diharapkan dapat tumbuh berbagai kegiatan belajar siswa sehubungan dengan kegiatan belajar siswa. Dengan kata lain terciptalah interaksi yang edukatif. Dalam interaksi ini guru berperan sebagai penggerak atau pembimbing sedangkan siswa berperan sebagai penerima atau yang dibimbing. Proses interaksi ini akan berjalan baik apabila siswa banyak aktif dibandingkan guru. Kondisi siswa yang lebih aktif dapat meningkatkan minat siswa dan membuat siswa memiliki pengalaman pembelajaran yang kondusif sehingga akan mengembangkan kecerdasan atau intelegensi siswa.

Dalam kegiatan pembelajaran di kelas, quantum learning menggunakan berbagai macam metode seperti metode ceramah, tanya jawab, diskusi, demonstrasi, kerja kelompok eksperimen dan metode pemberian tugas. Metode ceramah bermanfaat mengetahui fakta yang sudah diajarkan dan proses pemikiran yang telah diketahui serta untuk merangsang siswa agar mempunyai keberanian dalam mengemukakan pertanyaan, menjawab atau mengusulkan pendapat. Metode demonstrasi membantu siswa dalam memahami proses kerja suatu alat, membuat pelajaran menjadi lebih jelas dan lebih konkrit serta menghindari verbalisme, merangsang siswa untuk lebih aktif mengamati dan dapat mencobanya sendiri. Metode kerja kelompok akan membuat siswa aktif mencari bahan untuk menyelesaikan tugas dan menggalang kerja sama dalam kekompakan dalam kelompok. Metode eksperimen membantu siswa untuk mengerjakan sesuatu, mengamati prosesnya dan mengamati hasilnya, membuat siswa percaya pada kebenaran kesimpulan percobaannya sendiri. Metode pemberian tugas membina siswa untuk mencari dan mengolah sendiri informasi dan komunikasi serta dapat membantu siswa mengembangkan kreatifitasnya. Metode yang dikemukakan tersebut tidak ada yang sempurna bila berdiri sendiri, sehingga harus digunakan secara bergantian untuk saling melengkapi kekurangankekurangan yang ada (Surachmad \& Sunaryo, 2001).

Penggunaan berbagai metode penyajian pelajaran secara bergantian akan membuat siswa menikmati kegiatan pembelajaran dan tidak merasakan belajar yang monoton, serta perbedaan karakteristik pada siswa dapat terlayani dengan baik. Menurut Eggen dam Kauchak yang dikutip oleh (Surachmad \& Sunaryo, 2001) siswa belajar secara efektif bila siswa secara 
aktif terlibat dalam pengorganisasian penemuan pertalian-pertalian dalam informasi yang dihadapi.

Siswa dikatakan aktif jika ikut serta mempersiapkan pelajaran, gembira dalam belajar, mempunyai kemauan dan kreatifitas dalam belajar, keberanian menyampaikan pendapat atau gagasan serta ide pembelajaran quantum learning lebih mengutamakan keaktifan peran serta siswa dalam berinteraksi dengan situasi belajarnya melalui panca inderanya baik melalui penglihatan, pendengaran, perabaan, penciuman dan pengecapan, sehingga hasil penelitian quantum learning terletak pada modus berbuat yaitu katakan dan lakukan, dimana proses pembelajaran quantum learning mengutamakan keaktifan siswa, siswa mencoba mempraktekan media melalui kelima inderanya sehingga dapat meningkatkan daya ingat hingga 90\%. Semakin banyak indera yang terlibat dalam interaksi belajar, maka materi pelajaran akan semakin bermakna dan hal tersebut tentunya akan meningkatkan pemahaman dan hasil belajar siswa. Berdasarkan uraian yang telah dijabarkan, penelitian tindakan kelas ini dapat dilakukan karena masalah yang diangkat bisa dikembangkan berkelanjutan dalam kurun waktu tertentu (Susilo, 2012).

\section{METODE PENELITIAN}

Penelitian ini dilaksanakan dengan menggunakan rancangan penelitian tindakan kelas (classroom action research). Penelitian ini dilaksanakan dalam 2 siklus, setiap siklus dalam penelitian memiliki 4 tahapan kegiatan yaitu: (1) perencanaan, (2) pelaksanaan, (3) pengamatan, (4) refleksi (Arikunto, 2010). Pertemuan 1 siklus I membahas mengenai pengertian dan sifat logaritma, pertermuan 2 membahas mengenai fungsi logaritma dan grafik fungsi logaritma. Kemudian, pertemuan 1 siklus II membahas mengenai persamaan logaritma. Pertemuan 2 membahas mengenai fungsi larutan penyangga dalam tubuh makhluk hidup. Pengambilan data pada penelitian ini dilaksanakan sekitar bulan September hingga November. Penelitian dilakukan di kelas XI MIA 1 Madrasah Aliyah Negeri 1 Banjarmasin. Subjek penelitian di kelas X MIA terhadap 34 orang yang terdiri dari atas 14 orang siswa laki-laki dan 20 orang siswa perempuan.

Pengumpulan data dilakukan dengan dua teknik yaitu teknik tes dan non tes. Teknik ini digunakan untuk memperoleh data hasil belajar kognitif yang dicapai oleh siswa setelah mengikuti pembelajaran dengan model quantum learning. Teknik ini dilakukan dengan pemberian beberapa soal uraian. Kemudian teknik nontes digunakan untuk memperoleh data aktivitas 
guru dan aktivitas siswa melalui observasi/pengamatan. Data penelitian yang dikumpulkan berupa keterlaksaanaan aktivitas yang dilakukan guru selama pembelajaran menggunakan model quantum learning, aktivitas siswa, hasil belajar kognitif, hasil belajar afektif, intelegensi siswa serta respon siswa terhadap model quantum learning.

Keberhasilan siswa dalam memahami materi ditunjukkan dengan adanya siswa yang menjawab benar pada setiap butir soal yang diujikan. Selanjutnya untuk mendeskripsikan keberhasilan siswa tersebut, maka dibandingkan dengan kriteria yang telah ditetapkan dimana rata-rata nilai hasil belajar siswa $(\bar{x}) \geq 70$, daya serap (DS) $\geq 70 \%$ dan ketuntasan belajar siswa (KB) $\geq 85 \%$.

Analisis respon siswa dilakukan untuk mengetahui bagaimana tanggapan dan ketertarikan siswa terhadap pembelajaran materi fungsi logaritma menggunakan model pembelajaran quantum learning. Angket respon dibagikan kepada siswa setelah tes pada siklus II. Angket respon siswa berisi 12 pernyataan dengan pilihan jawaban yang diberi skor sangat tidak setuju $(\mathrm{STS})=1$, tidak setuju $(\mathrm{TS})=2$, ragu-ragu $(\mathrm{RR})=3$, setuju $(\mathrm{S})=4$ dan sangat setuju (SS) $=5$.

Indikator keberhasilan dalam penelitian ini adalah keterlaksanaan aktivitas pembelajaran yang dilakukan oleh guru ketika mengajar menggunakan model quantum learning minimal mencapai kategori baik. Selain itu, aktivitas siswa dalam melaksanakan pembelajaran mengalami peningkatan minimal kategori aktif. Kemudian, intelegensi siswa dikatakan telah optimal jika intelegensi siswa minimal mencapai kategori baik. Selanjutnya, hasil belajar kognitif dikatakan telah optimal apabila rata-rata nilai hasil belajar siswa $(\bar{x}) \geq 70$, daya serap (DS) $\geq 70 \%$ dan ketuntasan belajar siswa $(\mathrm{KB}) \geq 85 \%$. Lebih jauh lagi, hasil belajar afektif siswa dalam melaksanakan pembelajaran dikatakan optimal jika mencapai minimal kategori baik dan respon siswa terhadap model pembelajaran quantum learning dikatakan berhasil apabila menunjukkan hasil yang positif.

\section{HASIL PENELITIAN DAN PEMBAHASAN}

\section{Hasil Penelitian}

Aktivitas yang dilakukan guru selama pembelajaran menggunakan model quantum learning dan aktivitas siswa, hasil belajar kognitif, afektif, intelgensi dan respon siswa. Adapun skor peningkatan aktivitas yang 
dilakukan guru selama pembelajaran menggunakan model quantum learning pada siklus II jika dibandingkan dengan siklus I dapat dilihat pada Tabel 1.

Tabel 1. Hasil observasi keterlaksanaan pada siklus I dan II

\begin{tabular}{ccc}
\hline \multicolumn{2}{c}{ Siklus I } & Siklus II \\
\hline $\begin{array}{c}\text { Pertemuan I } \\
19,30\end{array}$ & Pertemuan II & Pertemuan I \\
26,30 & 31,66 \\
\hline Rata-Rata $=22,80$ & Rata-Rata $=31,66$ \\
Kategori $=$ Cukup & Kategori $=$ Baik \\
\hline
\end{tabular}

Pada siklus I diperoleh skor hasil penilaian observer untuk keterlaksanaan penerapan model quantum learning oleh guru dalam pembelajaran sebesar 22,80\% dalam kategori baik meningkat sebesar 8,86 menjadi 31,66 dalam kategori sangat baik pada siklus II. Skor peningkatan aktivitas siswa pada siklus II jika dibandingkan dengan siklus I dapat dilihat pada tabel 2 .

Tabel 2. Hasil observasi aktivitas siswa pada siklus I dan II

\begin{tabular}{ccc}
\hline \multicolumn{2}{c}{ Siklus I } & Siklus II \\
\hline $\begin{array}{c}\text { Pertemuan I } \\
11,35\end{array}$ & Pertemuan II & Pertemuan I \\
13,35 & 20,56 \\
\hline Rata-Rata $=12,35$ & Rata-Rata $=20,56$ \\
Kategori $=$ Cukup & Kategori $=$ Aktif \\
\hline
\end{tabular}

Pada siklus I diperoleh skor hasil penilaian observer untuk aktivitas siswa sebesar 12,35 dalam kategori cukup aktif dan meningkat sebesar 8 menjadi 20,56 dalam kategori aktif pada siklus II. Skor peningkatan afektif siswa pada siklus II jika dibandingkan dengan siklus I dapat dilihat pada tabel 3.

Tabel 3. Hasil observasi afektif siswa pada siklus I dan II

\begin{tabular}{ccc}
\hline \multicolumn{2}{c}{ Siklus I } & Siklus II \\
\hline $\begin{array}{c}\text { Pertemuan I } \\
7,74\end{array}$ & Pertemuan II & Pertemuan I \\
12,06 & 20,56 \\
\hline Rata-Rata $=9,90$ & Rata-Rata $=15,26$ \\
Kategori $=$ Kurang & Kategori $=$ Aktif \\
\hline
\end{tabular}


Pada siklus I diperoleh skor hasil penilaian observer untuk afektif siswa sebesar 9,90 dalam kategori kurang baik dan meningkat sebesar 9,36\% menjadi $15,26 \%$ juga dalam kategori baik pada siklus II. Skor peningkatan intelegensi siswa pada siklus II jika dibandingkan dengan siklus I dapat dilihat pada tabel 4.

Tabel 4. Peningkatan intelegensi siswa pada siklus I dan II

\begin{tabular}{ccc}
\hline & Rata-Rata Skor & \\
Pertemuan I & Pertemuan II \\
\hline 41,42 & 54,24 \\
Kategori = Cukup & Kategori = Baik \\
\hline
\end{tabular}

Pada siklus I diperoleh persentase hasil penilaian observer untuk psikomotor siswa sebesar 41,42 dalam kategori cukup tinggi dan meningkat sebesar 12,82 menjadi 54,24 dalam kategori terampil pada siklus II. Sesuai tahapan dalam PTK maka dilakukan evaluasi atau tes kognitif pada akhir pembelajaran di setiap siklusnya. Berdasarkan tes hasil belajar rata-rata nilai hasil belajar $(\bar{x})$ dari 60,29 menjadi 76,47 . Peningkatan rata-rata nilai hasil belajar siswa dari siklus I ke siklus II siswa dapat dilihat pada gambar 1.

Kemudian daya serap juga meningkat dari 60,29 menjadi 76,47 dan ketuntasan belajar meningkat dari 32,35 menjadi 82,35. Peningkatan daya serap dan ketuntasan belajar pada siklus I dan siklus II yang dapat dilihat pada gambar 2. Angket respon siswa diberikan pada tahap akhir pembelajaran siklus II dengan tujuan untuk mengetahui tanggapan 34 orang siswa kelas $\mathrm{X}$ MIA 1 pada pembelajaran fungsi logaritma menggunakan model quantum learning berbantuan modul. Hasil perhitungan menunjukkan bahwa diperoleh persentase sebesar $12,50 \%$ untuk respon cukup baik, $67,64 \%$ untuk respon baik dan $23,59 \%$ untuk respon sangat baik.

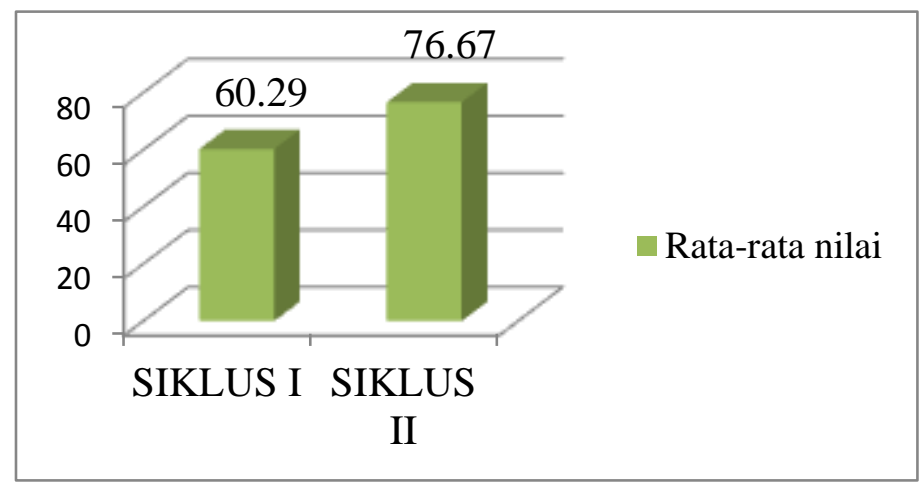

Gambar 1. Rata-rata Nilai Hasil Belajar Siswa pada Siklus I dan II 


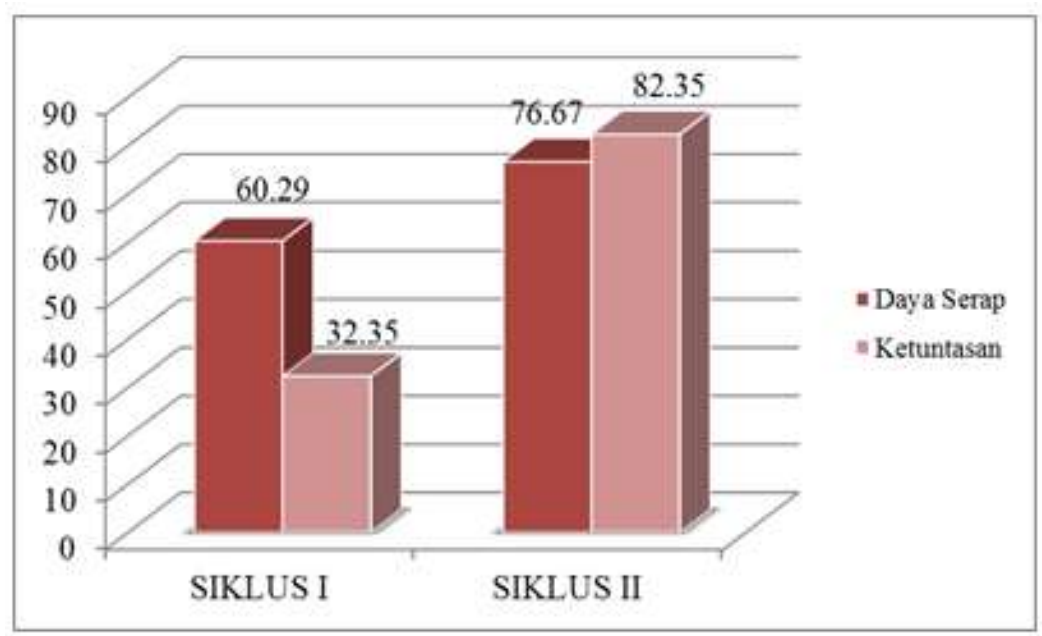

Gambar 2. Daya Serap dan Ketuntasan Belajar pada Siklus I dan II

\section{Pembahasan}

Penelitian ini menggunakan model pembelajaran quantum learning dalam upaya meningkatkan intelegensi dan hasil belajar siswa pada materi fungsi logaritma. Berdasarkan hasil penelitian yang telah dipaparkan oleh peneliti bahwa skor aktivitas guru dalam pelaksanaan proses pembelajaran pada pertemuan I dan pertemuan II siklus I secara beturut-turut adalah 19,30 dan 23,60. Hasil tersebut masih belum mencapai kriteria minimal dari persentase skor yang diharapkan oleh peneliti.

Untuk memperbaiki hasil tersebut, siklus II dilakukan. Pada siklus II rata-rata skor aktivitas guru dalam pelaksanaan proses pembelajaran mengalami peningkatan sebesar 8,06 dari 23,60 pada siklus I menjadi 31,66 pada siklus II. Peningkatan pada siklus II ini juga terjadi karena pada siklus II, guru lebih mampu dalam melakukan kegiatan pembelajaran dengan baik dibandingkan pada siklus I. Pelaksanaan pembelajaran di siklus II, pengelolaan waktu lebih efektif dibandingkan pada siklus I dimana guru telah melakukan beberapa tahap kegiatan pembelajaran sesuai dengan rencana proses pembelajaran (RPP) sesuai waktu yang disediakan.

Peningkatan pada siklus II ini juga terjadi karena pada siklus II, guru guru lebih mampu dalam melakukan kegiatan pembelajaran dengan baik dibandingkan pada siklus I. Pelaksanaan pembelajaran di siklus II, pengelolaan waktu lebih efektif dibandingkan pada siklus I dimana guru telah melakukan beberapa tahap kegiatan pembelajaran sesuai dengan rencana proses pembelajaran (RPP) sesuai waktu yang disediakan. 
Selain itu, karena pembelajaran siklus II guru mampu menarik perhatian siswa dalam memberikan apersepsi maupun menyampaikan tujuan pembelajaran dengan baik, pengelolaan waktu dan kelas sudah membaik sehingga pembelajaran pada setiap pertemuan siklus II terus meningkat. Keterlaksanaan penerapan model quantum learning berbantuan modul oleh guru pada pembelajaran meningkat dan berada dalam kategori baik.

Sedangkan untuk aktivitas siswa, rata-rata skor aktivitas siswa pada pertemuan satu adalah 11,35 dengan kategori kurang aktif. Hal itu menunjukkan bahwa masih terdapat beberapa kekurangan dalam beberapa aspek. Hal ini karena guru belum mampu membimbing dan mengajak siswa untuk berpartisipasi aktif dalam proses pembelajaran sehingga perlunya perbaikan dari guru untuk mengajak siswa berpartisipasi aktif dalam pembelajaran agar siswa dapat menemukan konsep yang akan ditemukan selama proses belajar agar dapat meningkatkan aktivitas belajar siswa. Pertemuan kedua siklus I tampak ada kemajuan pada aktivitas siswa. Hal ini ditunjukkan dari rata-rata skor observasi aktivitas siswa meningkat dari 11,35 menjadi 13,35 dengan kategori cukup aktif. Hasil tersebut masih belum mencapai kriteria minimal dari persentase skor yang diharapkan oleh peneliti. Untuk memperbaiki hasil tersebut, siklus II dilakukan.

Pada siklus II, aktivitas siswa meningkat dibandingkan dengan siklus I yang berada pada kategori aktif dengan perolehan hasil sebesar 20, 56. Banyak perbaikan yang telah dilakukan oleh guru dalam pembelajaran siklus II. Siswa juga lebih siap dalam belajar, siswa lebih aktif dalam kegiatan pembelajaran siswa bekerjasama dan berdikusi dengan teman satu kelompoknya. Jika dilihat pada setiap siklus maka aktivitas siswa dari siklus I ke siklus II mengalami peningkatan yang cukup signifikan, di mana pada siklus I rata-rata skornya sebesar 13,35 dengan kategori cukup aktif meningkat pada siklus II dengan rata-rata skor sebesar 20,56 dengan kategori aktif. Peningkatan aktivitas siswa yang terjadi sebesar $21,68 \%$.

Hasil belajar afektif meningkat dari rata-rata skor 9,88 dengan kategori cukup baik pada siklus I menjadi 15,29 dengan kategori baik pada siklus II. Hasil belajar kognitif meningkat dari rata-rata nilai hasil belajar $(\bar{x})$ dari 60,29 menjadi 76,47. Kemudian daya serap juga meningkat dari 60,29 menjadi 76,47 dan ketuntasan belajar meningkat dari 32,35 menjadi 82,35. Intelegensi siswa meningkat dari rata-rata skor 41,24 dengan kategori cukup pada siklus I menjadi 54,24 pada siklus II. 
Peningkatan hasil belajar dan intelegensi yang dicapai siswa tidak terlepas dari aktivitas siswa saat proses pembelajaran berlangsung. Siswa telah aktif dalam kegiatan diskusi baik diskusi dan saling bekerjasama dan berkomunikasi dalam kelompoknya. Melalui kegiatan belajar kelompok, siswa belajar menyampaikan pendapat berdasarkan pemahaman materi yang dibebankan sehingga konsep yang dapat diingat dengan angka waktu yang lebih lama, sementara siswa dengan kelompok kemampuan rendah dapat bebas bertanya dengan teman dalam kelompok dengan kemampuan tinggi tanpa ada perasaaan malu.

Siswa secara keseluruhan memberikan respon yang baik/positif terhadap pembelajaran dengan menerapkan penggunaan model quantum learning pada materi fungsi logarima. Hal ini berdasarkan hasil yang menunjukkan bahwa diperoleh persentase sebesar $12,50 \%$ untuk respon cukup baik, $67,64 \%$ untuk respon baik dan $23,59 \%$ untuk respon sangat baik.

\section{SIMPULAN}

Berdasarkan hasil penelitian yang telah dilakukan di kelas X MIA 1 Madrasah Aliyah Negeri 1 Banjarmasin tahun pelajaran 2017/2018 dapat disimpulkan bahwa keterlaksanaan aktivitas yang dilaksanakan guru selama proses pembelajaran menggunakan model quantum learning meningkat dari rata-rata skor 21,45 dengan kategori cukup pada siklus I menjadi 31,66 dengan kategori baik pada siklus II. Aktivitas siswa selama proses pembelajaran menggunakan model quantum learning meningkat dari rata-rata skor 12,35 dengan kategori cukup aktif pada siklus I menjadi 20,56 dengan kategori aktif pada siklus II. Hasil belajar afektif meningkat dari rata-rata skor 9,88 dengan kategori cukup baik pada siklus I menjadi 15,29 dengan kategori baik pada siklus II. Sejalan dengan itu, hasil belajar kognitif meningkat dari rata-rata nilai hasil belajar $(\bar{x})$ dari 60,29 menjadi 76,47. Kemudian daya serap juga meningkat dari 60,29 menjadi 76,47 dan ketuntasan belajar meningkat dari 32,35 menjadi 82,35 . Kemudian intelegensi siswa meningkat dari rata-rata skor 41,24 dengan kategori cukup pada siklus I menjadi 54,24 pada siklus II dan siswa memberikan respon yang positif terhadap pembelajaran dengan menerapkan penggunaan model quantum learning pada materi fungsi logaritma.

\section{DAFTAR PUSTAKA}

Adi, A., Dafik, Hobri, \& Sugeng, D. (2013). Pengembangan perangkat 
pembelajaran matematika berkarakter berbasis quantum teaching pada pokok bahasan aritmatika sosial kelas VII SMP. Pancaran, 2 (1), 13-25.

Adityarini, Y., Waluyo, J., \& Aprilya, S. (2013). Penerapan model pembelajaran quantum learning dengan media flashcard untuk meningkatkan motivasi dan hasil belajar siswa kelas X di SMA Negeri 1 PurwoharjoBanyuwangi tahun pelajaran 2011/2012 (pada pokok bahasan animalia). Pancaran, 2 (2), 189-199.

Ahmadi, A. (2004). Pengaruh minat belajar terhadap pembelajaran. Yogyakarta: BPFEE.

Arikunto, S. (2010). Penelitian tindakan kelas. Jakarta: Bumi Aksara.

Budiman, A. (2009). Tes IQ remaja jilid 1. Bandung: Pustaka Grafika.

DePorter, B., \& Hernacki, M. (1992). Quantum learning. Jakarta: PT Mizan Publika.

Iskandar. (2009). Hubungan Intelegensi dan hasil belajar. Surabaya: Usaha Nasional.

Maslihah, S. (2011). Studi tentang hubungan dukungan sosial, penyesuaian sosial di lingkungan sekolah dan prestasi akademik siswa SMPIT assyfa boarding school Subang Jawa Barat. Jurnal Psikologi Undip, 10 (2), 103114 .

Sukiarti, N. K. (2009). Pengaruh tingkat intelegensi dan motivasi belajar. Semarang: UNNES Press.

Surachmad, \& Sunaryo. (2001). Guru dan anak didik dalam interaksi edukatif suatu pendekatan teoritis psikologis. Jakarta: Rineka Cipta.

Susilo, H. (2012). Pemanfaatan Kemampuan Melaksanakan Penelitian Tindakan Kelas/Penelitian Tindakan Sekolah Untuk Menunjang Proses Pendidikan Dan Pembelajaran Di Sekolah. Quantum, Jurnal Inovasi Pendidikan Sains, 3 (2), 81-102. 